\title{
Vrou as beeld van God, Deel 1: 'n Historiese ondersoek - Vanaf Genesis tot die Middeleeue
}

\author{
Yolanda Dreyer \\ Tydelik-deeltydse dosent: Department Praktiese Teologie \\ Universiteit van Pretoria
}

\begin{abstract}
Woman created in the image of God, Part 1: a historical investigation - from Genesis to the Middle Ages

This study indicates that the traditions in the Pentateuch, especially the creation traditions, implied the egalitarian status of man and woman as image of God. The context of this traditions, however, was patriarchal and thus opened the possibility of the exploitation of women. Though Genesis 1:27 does not specifically attest to the asymmetry between man and woman in patriarchal society, the fate of women in general was bound up with the presentation of God as a male creator. The implications of this presentation can be clearly seen in texts of the intertestamental period. The study points out the degree to which Philo's view of a hierarchy concerning man and woman as immanent to God's order of creation, strongly influenced Christian thought on the place of women. Since the "fall of woman" necessitates a "soteriology", women in general are portrayed negatively in patristic texts. Mary is seen as the positive counterpart of Eve. The image of women then becomes that of submission on account of their alienation from God. The article concludes with the view of Thomas Aquinas that the subservience of slaves is less than that of women, because in their case it is not an order of creation.
\end{abstract}

\section{INLEIDING}

Is vroue volwaardig mens? Op dié vraag sou daar seker in hierdie tyd 'n vanselfsprekende ja-antwoord gegee kon word. Maar dit was nie altyd so nie. Die geskiedenis 
van filosofiese en teologiese denke toon dit baie duidelik aan. Dit kan ook gesien word in die eksegetiese tradisie. Die teologiese en eksegetiese tradisie is beïnvloed deur die heersende antropologieë vanuit die filosofiese denke: "The construction of gender difference in the Christian tradition is connected with the reception of the philosophical systems of Platonism, Neoplatonism and Aristoteliansim, which were read into the Bible" (Gössmann 1996:198). Die Bybel en Bybeltekste is weer gebruik om die antropologie van die dag te legitimeer en aan te dui hoe die status quo 'n skeppingsordening van God is. Hierdie studie het as bedoeling om die uitleg van Genesis 1:27 ("God het die mens geskep as God se verteenwoordiger, as beeld van God het God die mens geskep, man en vrou het God hulle geskep") in die Joodse en Christelike tradisie as voorbeeld van so 'n legitimasie na te gaan. Daar word veral gefokus op die uitdrukking "beeld van God". Daarom word daar in die tweede deel van die artikel ook aandag gegee aan 1 Korintiërs 11:7. Die versameling opstelle in die werk, Image of God and gender models in JudaeoChristian tradition (1991), onder redakteurskap van Kari Elizabeth Børresen, dien as vertrekpunt. In hierdie artikel word aandag gegee aan vroue as beeld van God soos dit in die teologie in die periode tot en met die Middeleeue na vore gekom het.

\section{GENESIS 1:27: PENATATEUG-TRADISIES}

Die idee van die mens as beeld van God is fundamenteel in teologiese antropologie. Dit lê 'n verband tussen God en mens. Hierdie verband raak dus die verhouding tussen die konsep wat die mens van God het en wat as "mens" gedefinieer kan word. Dit waarop die uitdrukking "beeld van God" betrekking het, is in die verlede nie dikwels met spesifieke verwysing na geslag bespreek nie. Die tradisionele Christelike modelle van geslagtelikheid is in die laat antieke tyd, die Middeleeue en die Reformasie gekonstrueer. Die periode vanaf die Reformasie sal in ' $n$ volgende artikel aandag kry.

Teenoor die klassieke uitleg van Genesis 1:27 verstaan kontemporêre teoloë die metafoor "beeld van God" in die algemeen in 'n egalitêre sin. Daar word aanvaar dat die vrou op 'n gelykwaardige wyse ingesluit is in die saak waarna die term "beeld van God" verwys. 'n Voorbeeld hiervan is die eksegese van Phyllis Bird (1991:11-34; vgl ook Micks 1982:4-16). Sy meen dat hierdie teksvers 'n sentrale stelling binne die boek Genesis se skeppingsverhale is. Dit het gevolge vir die verdere nadenke oor die kanon se 
verwysing na die menslike natuur en die mens se plek binne die skeppingsorde. In Genesis word verwys na die mensheid as geheel. Dit mag nie verskraal word tot 'n individu of ' $n$ subgroep van die mensheid nie.

Histories-kitiese ondersoek het uitgewys dat die Pentateug opgebou is uit tradisies afkomstig van wat onder andere die Priesterlike bron en die Jawistiese bron genoem word. Volgens Bird het die figuur "Adam", wat die skeppingsverhale in Genesis betref, in die Priesterlike tradisie betrekking op die spesie "mens". Mens word kollektief verstaan en dit beteken dat albei geslagte insluit is. Die beeld van God, 'n onderskeidende kenmerk van die mensheid, gaan nie verlore wanneer mense ongehoorsaam is of wanneer God 'n oordeel oor hulle fel nie. Wat dit presies beteken om te sê dat die mens as beeld van God geskape is, word nie gespesifiseer nie en is dus oop vir interpretasie. Die strekking van die teks dui egter daarop dat die uitdrukking "beeld van God" in verband gebring moet word met die verantwoordelikheid om te "heers" (kyk Bird 1991:22; vgl ook Howe 1995:40). As kenmerk van menswees word daar dus van die manlike en vroulike komponente van die mensheid gevra om ten volle verteenwoordiger van God te wees en die verantwoordelikheid wat daarmee geïmpliseer word, te aanvaar. Dit impliseer verder sosiale reëlings binne die menslike gemeenskap asook ekologiese reëlings ten opsigte van die res van die skepping. Hierdie reëlings moet die beeld-van-God kwaliteit van mense sowel as hulle kollektiewe verantwoordelikheid vir God se skepping weerspieël.

Balans, wat gelykwaardigheid impliseer, is 'n sentrale kenmerk van hoe man en vrou in albei skeppingsverhale voorgestel word. In die Priesterlike tradisie word hierdie balans uitgedruk deur 'n simmetriese konstruksie, in die Jawistiese tradisie deur dramatiese aksie en interaksie. Die Priesterskrywers hanteer die verskil tussen geslagte suiwer op 'n biologiese vlak. Biologiese geslag, as verskillend en ook as eenheid, is bedoel vir voortplanting. Dit moet verstaan word as 'n God-gegewe gawe wat gepaard gaan met God se seën en opdrag. Die gawe is bedoel vir die hele mensheid. Die kwalifikasie "vul die aarde" het betrekking op die begin van die mensheid en geld nie vir alle tye nie. Die opdrag is ook nie absoluut of universeel nie. Dit moet herhaal en herinterpreteer word in veranderende historiese en ekologiese omstandighede. Die Jawis vul die Priesterskrywers aan deur te fokus op die psigo-sosiale betekenis van geslagtelikheid. Kame- 
raadskap, om werk te deel, wedersydse aantrekking en 'n band wat ander menslike verbondenheid (soos familiale of etniese oriëntasie) oorstyg, is hier die bedoeling van die verskil in geslagtelikheid: "these are the signs of intended partnership" (Bird 1991:23). Die individu moet dus buite haar- of homself gaan soek na die vervulling van basiese menslike behoeftes. Hierdie menslike noodwendigheid beteken dat die mens ' $n$ sosiale wese is wat binne gemeenskap lewe. Die nodig hê van 'n ander om basiese behoeftes te vervul, open egter ook die moontlikheid tot uitbuiting.

Vroue is byvoorbeeld uit hulle vader se huishouding uitgeneem en ingeneem in die huis van hulle man. In hulle lewe het 'n groot omwenteling plaasgevind terwyl die man wat met ' $n$ eie huishouding begin het, sy blyplek altyd min of meer in die omgewing van sy vader se huishouding behou het. Die vrou wat so in 'n "patrilokale residensie" opgeneem is, is eers ten volle as deel van die gemeenskap gereken wanneer sy geboorte aan 'n seun gegee het om sodoende die "familie van prokreasie" te dien. Indien sy kinderloos sou bly of nie seuns in die lewe sou bring nie, was sy 'n objek wat weggegooi kon word. In die voor-monargale tydperk in Israel se geskiedenis is sy angewend as objek van "seksuele gasvryheid" ter wille van haar man se "vriendskap" met ander mans wat sy ekonomiese en politieke stabiliteit tot diens kon wees. Tydens die monargale periode kon vroue deel van die buit wees wanneer mans militêre suksesse behaal. Hulle kon ook uitgebuit gewees het deurdat hulle volgens ekonomiese en politieke ooreenkomste vanuit die een haremgemeenskap oorgeneem kon word in ' $n$ ander. In die namonargale periode het hierdie posisie weer verander, maar nie tot vroue se voordeel nie. In hierdie tydperk het die priesters weer aangedring dat mans hulle "vreemde" vroue, afkomstig uit die ander "families van etniese oriëntasie", moes skei ter wille van etniese suiwerheid (vgl Malina [1981] 1993:159-161).

'n Voorbeeld van uitbuiting van vroue in huweliksgemeenskap in die leefwêreld van die Bybel is die werklikheid dat vrouwees per se onwaardigheid impliseer en manwees per se waardigheid. Julie Galambush (1992:6-9) wys daarop dat die profeet Esegiël God voorstel as 'n eggenoot wat Jerusalem as sy (let op manlike vorm) vrou neem. In Esegiël 3 word die tempel in Jerusalem uitgebeeld as die vrou se vagina en uterus (Galambush 1992:35-59). Die afgodery wat in die tempel gepleeg word (bv die offer van kinders - vgl Galambush 1992:96-97), word met die onreinheid van menstruasie verbind. 
'n Onaanvaarbare politieke alliansie word in Esegiël 4 vergelyk met huweliksontrou waaraan die vrou skuldig is (Galambush 1992:100-102). Wat ons hier aantref, is die beeld van God as verontregte man en die definisie van vrou as onwaardig.

Phyllis Bird meen nie dat hierdie ongelyke posisies tussen man en vrou in Genesis 1:27 teruggevind kan word nie. Bird (1991:25) is van oortuiging dat die teks self geen hiërargie van mense propageer nie: nie wat geslagtelikheid of funksie betref nie. Al die stellings verwys na die mensheid as geheel. Sy ontken egter nie dat die Priesterskrywers in 'n patriargale kultuur geleef het nie. Konsepte soos "beeld", "heers" en "onderwerp" is gewortel in manlike metafore. Sommige interpreteerders vind hierin regverdiging vir die tradisionele uitleg van "beeld van God". Maar Bird meen dat dit nie die skrywer se bedoeling was nie. Ook Horst Seebass (1996) stem hiermee saam. Oor die onderskeid wat in die kultus tussen geslagte gemaak word en oor die onderskeiding in die teks sê hy:

$\mathrm{Da} B$ solche Unterscheidung in Kultgesetzen eine rolle spielt, bedeutet nicht, $\mathrm{da} B$ solche hier vor Augen steht ... Als Einzeiler nach dem schönen Chiasmus V27a gibt V27b seine Pointe zu erkennen: Durch die Differenzierung in männlich und weiblich bleiben die Menschen davor bewahrt, sich mit dem einzigartigen Gott Israels zu vergleichen, der Geschlechtlichkeit nur für die Schöpfung bestimmt hat.

(Seebass 1996:82)

Die bedoeling word oorgedra deur die struktuur van die argument eerder as deur die kultuur bepaalde taal wat dien as die vorm van oordrag. Tog is die Priesterskrywers se taal onbetwisbaar androsentries en patriargaal gekleur. Die retoriek in die boodskap van Genesis 1 is egter volgens Bird nie patriargaal van aard nie. Dit is ook nie die boodskap van die Jahwis nie. Androsentrisme word in die Jawistiese tradisie gebalanseer met 'n eksplisiete narratiewe kwalifikasie: hoewel die vrou uit die man geneem is, sal hy haar “aanhang". Dominansie van man oor vrou word voorgestel as 'n gevolg van die sonde, nie as die bedoeling van die skepping nie (kyk Bird 1991:25). Juis teenoor die patriargale agtergrond waarteen die teks geskryf is, vind sommige eksegete dit merkwaardig dat vrou 
en man gelykwaardig geskape is na God se beeld. Van Wijk-Bos (1995:25) sien dit as 'n voorbeeld van ' $n$ teks wat die teks se eie beperkings oorstyg. Seebass (1996:83) stel dit so: "Zum Mann-Frau-Verhältnis: $P$ redet überall androzentrisch/patrilinear, vgl schon Kap.5. Um so bemerkenswerter ist, daß Mann und Frau gleichermaßen Ebenbilder Gottes sind und gemeinsam beauftragt werden!"

Wat die Priesterskrywers betref, stem William Beers (1992) egter nie saam met die sogenaamde neutrale strekking van die skeppingsverhale se boodskap nie. Uitgaande van die priesterlike aktiwiteit rondom offerrites, sê hy in sy boek Women and sacrifice: Male narcissism and the psychology of religion dat mans se selfliefde én vrees vir vroue uitgedruk word in die "ritual blood sacrifice". Hy noem dit 'n "anxiety about esteem, power, and differentiation." Hierdie selfliefde mak dit nodig om mag uit te oefen oor vroue. Volgens Beers (1992:169) oefen die Priesterskrywers mag uit deur te suggereer dat "sex has nothing to do with how God (or Nature) works." Hy wys daarop dat die verhaal oor die skepping wat vanuit niks en op grond van slegs 'n (manlike) "woordaksie" geskied (vgl ook Heb 11:3), die (natuurlike) rol van vroue heeltemal negeer: "The male God of the Genesis story creates without sex. There is no need for female presence in the creation of the world. Indeed woman came out of man, a reversal of biological fact" (Beers 1992:169).

Die (analogiese) idee dat God wel soos 'n man met 'n vrou seksuele gemeenskap het, is egter nie net 'n gedagte wat in die oud-Egiptiese en Grieks-Romeinse wêreld voorkom nie. Dit is ' $n$ voorstelling wat in sowel die Ou Testament as die Nuwe Testament voorkom. In Esegiël 16:8 word hierdie analogie gebruik om God se verbondsluiting met Jerusalem (uitgebeeld as 'n maagd) uit te druk (kyk Wevers 1969:121). In Lukas 1:35 word die geboorte van Jesus uit die maagd Maria op dieselfde manier verbeeld (kyk Daube 1957:119-120.) Daar is egter ook eksegete wat meen dat laasgenoemde teks nie seksuele konnotasies bevat nie (kyk Dibelius 1932:19-27; Brown 1979:124). Hoe dit ook al sy, in tekste soos Esegiël 16 en Lukas 1 word die rol van vroue by God se handeling ten minste nie verswyg nie. Maar wat die Jawistiese tradisie betref, is dit moontlik om, soos in die geval van die Priesterskrywers, te praat van die stilmaak van vroue-ervaring. Inger Ljung (1989), byvoorbeeld, wys in haar boek, Silence or suppression: Attitudes towards women in the Old Testament, daarop dat daar "sensuur" 
toegepas is deur die Jawis op materiaal vanuit die Noordelike Koninkryk (Israel). Hierdie materiaal het elemente bevat oor die betekenis wat vroulik georiënteerde Kanaänitiese vrugbaarheidsgodsdienste vir Israelitiese vroue gehad het, maar is deur die Jawis uitgehaal.

Waar William Beers kritiek uitspreek op die resultate van Phyllis Bird, beoordeel Alice Bach (1993:201) die werk van Bird (asook dié van die "feministiese" eksegete C Meyers [1988] en T Frymer-Kensky [1981]) in 'n positiewe lig:

These scholars attempt to read biblical narrative against the context of the dominant traditions and cultural milieux of the ancient world. By placing the text within the legal and social structures in which both authors and readers found themselves, the net of patriarchy emerges not as a villainous trap for women but rather the canvas on which the whole world, male and female, was painted (my beklemtoning).

Ook Phyllis Trible bevind haar in dieselfde geselskap as Phyllis Bird. Trible (1978:18) meen ook dat Genesis 1:27 die gelykwaardigheid van man en vrou beklemtoon: "Sexual differentiation does not mean hierarchy but equality. Created simultaneously, male and female are not superior and subordinate. Neither has power over the other; in fact, both are given equal power". Elisabeth Gössmann meen dat die pluraliteit van menswees uitgebeeld word in die skeppingsverhaal van Genesis 1 waar man én vrou geskape is. Sy betreur die feit dat Genesis 1 se weergawe in die Christelike tradisie afgeskeep is en die klem gelê is op die tweede skeppingsverhaal. Die gevolg hiervan was ' $\mathrm{n}$ wydverspreide siening dat “... all human beings, including women, derive from Adam as the primal model" (Gössmann 1996:199).

Juis ten opsigte van die patriargale agtergrond waarteen die teks geskryf is, vind ook Van Wijk-Bos (1995:25) dit merkwaardig dat vrou en man gelykwaardig geskape is na God se beeld. Sy sien dit as 'n voorbeeld waar 'n teks die eie beperkings en kultuur-bepaaldheid oorstyg. Hierteenoor meen Rosemary Radford Ruether (1991:262) egter dat Genesis 1:27, gesien in die konteks van die Ou Testament, glad nie verwys na die verhouding tussen die geslagte nie. Dit verwys gewoon na die feit 
van twee geslagte wat bestaan onder mense en diere, anders as by God waar geslagtelikheid nie ter sprake is nie. Die samelewing van die outeur van Genesis sou as vanselfsprekend aanvaar dat die "heers oor die skepping" uitgeoefen sou word deur die manlike familiehoof. In die praktyk is hierdie manlike familiehoof dan ook die korporatiewe verteenwoordiger van die mensheid (Ruether 1991:263). Sy beklemtoon die radikaal androsentriese bepaaldheid van die Joodse godsdiens. Dit word weerspieël in die reëlings ten opsigte van offerdiere. Vroulike diere was selfs onbruikbaar om geoffer te word in die tempelkultus. In al die verskillende soorte offers wat te doen het met die kern van die tempelkultus, is manlike offerdiere verlang. Slegs persone wat tot die laagste stand behoort het en wat 'n private offer wou bring, kon ook 'n vroulike offerdier gebruik (kyk Hultgård 1986:48-49).

\section{PATRIARGALE HIËRARGIE}

Wanneer teoloë vandag dus aanvaar dat Genesis 1:27 man en vrou op gelyke vlak sien as beeld van God, verdiskonteer hulle volgens Ruether nie die patriargale vooronderstellings van die Bybelse tyd voldoende nie. So 'n lees van 'n Bybelse teks vanuit 'n egalitêre en individualistiese perspektief gaan uit van die vooronderstellings van die moderne demokratiese samelewing en is daarom anachronisties van aard. Individualisme asook "demokratiese" uitgangspunte soos "vryheid" en "gelykheid" is vreemd aan die sosiale konteks van die antieke outeur (Ruether 1991:263).

Die Joodse geleerde, Judith Antonelli (1995:xxi-xxiii), glo nie dat die Tora die oorsprong van vrouehaat, seksisme of manlike dominansie is nie. Indien die Tora verstaan word binne die konteks waarin dit gegee is, het dit volgens haar vroue nie onderdruk nie, maar hulle status eerder verhoog.

The notion that male supremacy is rooted in the Bible beginning with the story of Adam and Eve, is a basic tenet of Western civilization. This universal tendency to attribute the origins of male domination to the "Old Testament" is primarily due to the spread of Christianity as the major religion of the West ... Christian misogyny is its own phenomenon, stemming mostly from the New Testament, the Church Fathers, and Greco-Roman paganism.

(Antonelli 1995:xxi, xxiii) 
Antonelli meen nie dat Judaïsme 'n patriargale godsdiens is nie. Die seksisme wat daar wel in Judaïsme voorkom, ontmasker sy as sosiologies van oorsprong eerder as om dit te sien as "die wet van God". Dit is waar dat daar sedert die vroegste tye in die Christendom karikature van Jode se oortuigings aangetref word. Die vroegste neigings tot anti-Semitisme (om so 'n anachronistiese term te gebruik) wat na die Nuwe Testament teruggevoer word, is egter nie as sodanig 'n Christelike tendens nie. Jesus se onkonvensionele optrede, wat in 'n sekere sin 'n aansluiting by sommige Ou-Testamentiese kontranarratiewe is, moet verstaan word as die protesoortuigings van 'n eerste-eeuse Israeliet, binne die pluraliteit van oortuigings, teen die hiërargies en eksklusief georiënteerde tempelideologie van eerste-eeuse Judeërs. Jesus se subversiewe en onkonvensionele betrokkenheid by vroue moet in hierdie lig verstaan word. Om hiërargie in hierdie leefwêreld as sosiologies en nie ook as religieus (of ook ekonomies, polities of familiaal) te sien nie, beteken om nie die verweefdheid van die eerste-eeuse Mediterreense kultuur in ag te neem nie.

Dit is algemene kennis dat die leefwêreld van die Bybel deur patriargale hiërargie gekenmerk is. Mense het in interaksie bestaan (die sogenaamde "diadiese persoonlikheid" van die Mediterreense kultuur). Bruce Malina (1996:45) formuleer dit soos volg:

Like many common beliefs held by historians, however, this one [individualism] too is an anachronistic, ethnocentric projection, asserted frequently but not.validated. In fact, the Mediterranean selves we read about in the Bible could not have been individualistic selves, very concerned to adopt the viewpoints of the groups (their in-groups) whose fate they shared.

Vroue se "lot" was onlosmaaklik aan 'n man (pa of eggenoot) gebind en dit hou verband met 'n patriargale Godsbeeld. Halvor Moxnes (1996:32) stel dit soos volg: "The three main religions that originated in the Middle East, Judaism, Christianity, and Islam, share the idea of a male creator god and corresponding ideas of a primary male role in procreation. Women have only a subsidiary role, which makes them inferior and creates a feeling of shame." Hierdie belewing waarin vroue gesosialiseer is, was in geheel in 
verband gebring met hulle seksualiteit. Die patriargale samelewing het van hulle 'n styl van sosiale interaksie verwag wat met die woord "kuisheid" beskryf kan word. Daar is duidelik raakpunte tussen vroue se seksualiteit, kuisheid (wat maar 'n ander woord vir "eer" of "skande" is) en die hiërargiese sosiale struktuur. Vroue wat die reëls rondom "kuisheid" verbygaan, bedreig die hiërargie. Moxnes (1996:33) beskryf dit soos volg:

Threats to establish bonds of sexuality are threats to the loyalties of this hierarchical society. Modesty codes (e.g., veiling) are a way of denying sexuality and showing acceptance of the existing social structure. For women the primary focus of this deferential attitude is their sexuality, but modesty [the female moral code of shyness, self-restraint, and a deferential attitude] is also important in other kinds of dependent relationships.

Carolyn Osiek en David Balch (1997:57) toon dat vroue se ondergeskikte inbedding in die wêreld van mans nie net in oud-Israel so was nie, maar dat dit ook die gebruik in die Grieks-Romeinse periode was:

In the family, the legal and social power of the father over wife, children, slaves, and property was extensive in all the ancient Mediterranean societies known to us .... In Roman law, the legal term is patria potestas, viewed by ancient writers as a unique degree of legal power. Theoretically it included the power of life and death (vita necisque potestas) ... (Osiek \& Balch 1997:56-57).

Om mag só te verstaan is om die man as die beeld van "god almagtig" te sien. Anders Hultgård (1991) wat ondersoek ingestel het na die Jodedom se interpretasie van die skeppingsverhale en die verhouding tussen geslagte in die algemeen, het ook bevind dat "women are implicitly regarded as not being created in the image of $Y H W H$ " (Hultgård 1991:50; my beklemtoning). Indien dit nie die geval sou wees nie, sou geredeneer kon word dat die semantiese gebruik van die woord "adam" generies is en vroue insluit. In die vroeg-Joodse geskrifte wat gebruik maak van die skeppingsverhale, 
is daar egter 'n baie sterk androsentriese perspektief. Die generiese term "adam" is dikwels gebruik om duidelik 'n manlike individu an te dui. Wanneer vroeg-Joodse dokumente dus verwys na die eerste skeppingsverhaal, gebruik dit die eienaam Adam. Die strekking van die tweede skeppingsverhaal word met ander woorde gebruik vir die verstaan van die eerste. In hierdie latere gebruik van die skeppingsverhale word die vrou, net soos in die voor-eksiliese dokumente, selde genoem. Slegs wanneer daar spesifieke belange ter sprake is, word verwys na geslagtelike verskille by die skepping (Hultgård 1991:39).

\section{VROEËRE JUDAÏSME}

Die volgende tekste gee ' $n$ aanduiding van die fundamentele idees ten opsigte van God en die vrou in die vroeë Judaïsme. Hierdie idees is gewoonlik nie eksplisiet gemaak nie. Die tekste kom uit verskillende tydperke en reflekteer verskillende gesigspunte en belange (kyk Hultgård 1991:40-45). Dit word hier kortliks weergegee sodat die gang van die denke oor die saak gevolg kan word.

Tobit 8:6 selekteer elemente uit die skeppingsverhale wat aantoon dat die man voorrang geniet. Elemente wat die rol van vroue definieer, is duidelik aanduibaar. Vroue se rol word gesien vanuit mans se perspektief: vroue is gemaak om mans te ondersteun. Verder word hulle rol gesien uit die perspektief van die mensheid: man en vrou saam het die taak om voort te plant. "These characteristics are typified in Adam and Eve, the primordial couple, and repeated in all subsequent unions of man and woman" (Hultgård 1991:40).

Jubileë kan beskou word as 'n "komplementêre parafrase" van die skeppingsverhale in Genesis. Die Sadduseërs (die mees invloedryke groep binne die Joodse gemeenskap in die Hellenistiese periode) stel in die besonder belang in die wetlike aspekte van die Tora. Dit kom sterk na vore in Jubileë. Ook hier geniet "Adam" voorrang. Die wyse waarop die wet man en vrou verskillend behandel, asook reinheidsmaatreëls ten opsigte van vroue, word direk teruggevoer na die skepping. Die Sibillynse Orakels (I en II) is die produk van Griekssprekende Jode in Klein-Asië in die tussentestamentêre periode. Hier word die "beeld van God" slegs op Adam toegepas. In die Slawiese Henogboek, hoofstukke 24-32, gee God aan Sofia (Wysheid) die taak om Adam te maak. 
Hierdie dokument is in die eerste eeu $\mathrm{nC}$ binne 'n diasporagemeenskap geskryf. Jahwe gee aan Adam die vrye wil om vir of teen God te kies (Slaw Hen 30:15). Die skepping van Eva word na aanleiding van Genesis 2:21-22 kortliks beskryf en daar word bygevoeg: "Ek het vir hom 'n vrou geskep, sodat die dood na hom kon kom op grond van sy vrou" (Slaw Hen 30:17).

Haggadiese vertellings oor die eerste twee mense is versamel in die boek Die lewe van Adam en Eva. Hier word die uitdrukking "beeld van God" toegepas op die man en sy manlike nageslag. Die "beeld van God" kwaliteit van die vrou word nie eksplisiet ontken nie. Dit word egter duidelik dat "beeld van God" weer eens 'n voorreg is wat gereserveer word vir die man. Hierdie voorreg is an die man gegee by die skepping. Filo van Aleksandrië het 'n groot invloed gehad op nie net die Judaïsme nie, maar ook op die Christelike tradisie. Sy siening van geslagtelikheid kan soos volg beskryf word: “... Philo's gender categories are among the most rigid and consistently applied principles of his thought" (Mattila 1996:103). Vroeg in die eerste eeu het Filo die twee skeppingsverhale gekombineer en die skepping van die mens beskryf in twee stadia. Sy traktaat, De Opificio Mundi, beskryf die eerste mens as 'n wese wat manlike en vroulike beginsels insluit. Die mens het verkeer in ' $n$ hemelse staat van nie-geslagtelike lewe. Hierdie wese is geskape na die beeld van God en verteenwoordig die ideale mens. In die tweede fase van die skepping van die mens is lewende kopieë van die argetipe gemaak. Eers was daar 'n beliggaamde manlike androgene wese, die hoër manlike vorm (die "oorspronklike" Adam) en daarna het die laer vroulike vorm afgeskei. Hierdie visie op die skepping kom ook in die Talmud voor: "Deze opvatting vindt men in de Talmud. Daarin treft men de haggadische verklaring aan, dat God bij de eerste schepping de mens heeft geschapen met twee gezichten en hem later gesplitst heeft" (Gispen 1974:78). Die verhaal van die sondeval illustreer volgens Filo dat die man meer waarde het as die vrou. Op grond van sy allegoriese interpretasie is die dieper betekenis van die verhaal om aan te dui dat die manlike beginsel van "rede" veel hoër waarde het as die laer vroulike beginsel van "sintuiglikheid" (kyk Hultgård 1991:44; Ruether 1991:265).

Die eerste-eeuse Farisese geskiedskrywer, Josefus, harmonieer die twee skeppingsverhale in sy Antiquitates Judaica, maar sien die Jawis se weergawe as die eintlike skeppingsverhaal. Hy verplaas die stelling "manlik en vroulik het God hulle geskape" na 
die gedeelte oor die diere en bring dit in verband met Adam se taak om aan die diere name te gee. Die vroeg-Christelike skrywer Paulus se beskouing van man en vrou korreleer in 'n sekere sin met die idees binne die Judaïsme. 'n Mens kan Paulus se interpretasie van die skeppingsverhale in Genesis in 1 Korintiërs 11:2-16 verneem: "Hy [die man] is die beeld en die heerlikheid van God, maar die vrou is die heerlikheid van die man" (1 Kor 11:7b). Net die man is dus die beeld van God. Die vrou is uit die man gemaak en is gemaak ter wille van die man (vers 8-9).

Die meeste Joodse tekste praat egter in sulke algemene terme dat dit moeilik is om tussen die geslagte te onderskei. Tog is die Mediterreense samelewing basies volgens die geslagte ingedeel:

\begin{abstract}
While family reliance is the core value supported by the prevailing social institution of kinship, yet all valued persons or objects are primarily gender defined. This means that an individual is primarily male or female (secondarily a group-embedded person, thirdly a person with a name). Not only are selves defined by gender, but so are other things, including nature, times, and places ... Similarly, as regards times, women must come after men and leave before them or must be duly chaperoned. Some places are distinctively female .... Male places are those on the outside .... (Malina 1996:50).
\end{abstract}

In hierdie wêreld word die mensheid meesal verteenwoordig deur die eerste manlike individu, dit wil sê Adam. In sommige tekste uit die Jodedom waar spesifieke sake aan die orde kom, sien ons dat vroue op godsdienstige en morele gebied geëvalueer word. Die resultaat van die evaluasie is dat vroue te kort skiet ten opsigte van mans en daarom 'n minderwaardige geslag is. Die Jawis se skeppingsverhaal word dikwels in hierdie interpretasies as die norm gebruik. Hierdie verhaal verskaf die onderbou en regverdiging vir die ondergeskikte rol wat binne die Joodse samelewing, gevorm deur 'n manlik-georiënteerde ideologie, aan vroue toegeken word (Hultgård 1991:50).

\title{
5. IN DIE VROEË CHRISTENDOM
}

Aan die begin van die Christendom is vroue ingesluit in die toelatingsritueel, naamlik die doop. Vroue en mans is beskou as verlostes. Die vraag is hoe dit vroue se geestelike en 
sosiale status in die kerk beïnvloed het? Is manlike dominansie oor getroude vroue oorkom onder gedooptes? Het die selibaat vroue gelyke geestelike gesag met mans gegee? Om antwoorde te vind oor die veranderde status van gedoopte vroue, is terugverwys na die Joodse en Hellenistiese interpretasies van die skeppingsverhale (kyk Ruether 1991: 264-267). Vanweë Filo se siening van die skepping van die mens, was die ordening tussen die geslagte hiërargies van aard. Die hiërargiese verhouding tussen die geslagte was vir hom die voorbeeld van hoe die verhouding tussen God en mens, asook die relasie tussen die liggaam en die siel, daar uitsien.

Sommige Christene het die driedeling sarks, psuche en pneuma aanvaar. Die psuche was die tussenganger en sensuele deel van die siel. Dit was analoog aan die vroulikheid van die liggaam in relasie tot die manlikheid van die rede. Daar is gereken dat sowel mans as vroue oor al drie komponente beskik het. Manlikheid en vroulikheid het simbole van geestelike volwassenheid (manlik) of laer sensualiteit (vroulik) geword. Vroue wat geestelik ontwikkeld was, was byvoorbeeld vry van ondergeskiktheid en kon manlike spirituele gesag uitoefen (kyk Ruether 1991:267).

Gnostiese denke, weer, was dualisties bepaald en het onderskei tussen die liggaam as iets totaal apart van die ware, intelligente, geestelike mens. Laasgenoemde is geskape na die beeld van God. Die verskille tussen manlik en vroulik was nie net in liggaamlikheid te bespeur nie, maar ook in die hoër, geestelike sfeer. Die manlike element van die geestelike is aangedui as pneuma (Tatianus en Origenes) en nous (Die onderrig van Silvanus). Pneuma, so is gemeen, het voorrang bo die laer vroulike element, die psuche, geniet. Die psuche is beskou as verantwoordelik vir swakheid, vir die neiging tot die sintuiglike (Tatianus), vir die neiging om oorweldig te word deur passie en die kwaad (Origenes; Die onderrig van Silvanus). Geslagtelike differensiasie wat gebruik is om te verduidelik hoe die mens se innerlike funksioneer, toon ook duidelik 'n hiërargiese ordening van die elemente aan. Balans kon alleen bereik word as die laer, slegter deel ondergeskik en onder beheer gebly het van die hoër, beter deel. Om "beeld van God" te wees was die uitsluitlike prerogatief van die manlike element, die nous of pneuma. Geslagtelike differensiasie was vreemd aan die volmaakte arche, die volmaakte mensheid wat die beeld van God weerspieël. Geslagtelike differensiasie was 'n saak van hierdie bedeling en sou in die eindtyd verdwyn. Dan sal die volmaakte mensheid herwin word in die 
unieke vorm van Christus. Dan sal die beeld van God weer herstel wees. Hierdie formulerings het die grondslag van die tradisie wat die beeld van God beperk tot die manlike, gevorm (Gasparro 1991:157-158).

In gnostiese tekste of tekste wat 'n gnostiese invloed vertoon, word die uitdrukking gebruik dat 'n vrou "manlik word". Die kategorieë "man" en "vrou" is met ander woorde gepolariseer. Om "manlik te word" het beteken dat 'n ontwikkeling by die vrou moes plaasvind, sodat sy van 'n laer staat van menswees na 'n hoër vlak van geestelikheid en moraliteit kon oorgaan. Die omgekeerde was ook moontlik, naamlik dat 'n man "vroulik kon word". Dit was 'n aanduiding dat 'n man vanaf sy hoër staat geestelik en moreel gedegenereer het. Die gebruik van hierdie metafoor in vroeg-Christelike denke gaan terug op Efesiërs 4:13 se gebruik van die term "volmaakte man" (teleios aner). Klemens van Aleksandrië was die eerste Christelike skrywer wat in sy gebruik van Efesiers 4:13 prominensie verleen het aan die uitdrukking teleios aner. Die Christelike man word beskryf as die "volmaakte man". Klemens se geskrifte kom uit die tydperk vanaf die einde van die tweede tot die begin van die derde eeu nC. In sy geskrif Stromata (VI, 100:3) verwys hierdie kerkvader na 'n vrou wat haarself bevry het van verbondenheid aan die "vlees" en volmaaktheid bereik het net soos haar man. Verder word daar gesê dat siele nie manlik of vroulik is nie (Vogt 1991:172-173, 177).

Volgens Origenes is die vrou wat man geword het en nie meer vroulik is nie, die volmaakte, manlike vrou. Hierdie siening polariseer "manlik" en "vroulik" baie sterk en dit het weer konsekwensies vir Origenes se antropologie en etiek. Die manlike deel van die innerlike mens, naamlik die siel of gees, is beter en van meer waarde as die vroulike deel, die anima, oftewel die sintuie. Manlike en vroulike kategorieë beskryf nie net die samestelling van die innerlike hiërargie nie, maar word ook metafories gebruik vir morele eienskappe. "Vroulik" is alles wat swak, sensueel, lui en afhanklik is, en kan direk gekoppel word aan die domein van die sonde. Dit is 'n bekende tema in patristiese literatuur. Die konsekwensie hiervan is dat Origenes geslagtelikheid vergeestelik. Ware geslagtelikheid is 'n saak van die innerlike mens. Dit is die morele en geestelike kwaliteit van die innerlike mens wat bepaal of die individu "man" of "vrou" genoem moet word. 'n Vrou van hoër geestelike kwaliteit kan 'n man word, en 'n man wat verval het, kan 'n vrou word en verlore gaan (Vogt 1991:178). 
Didimos die Blinde van Aleksandrië toon weer met sy eksegese van Genesis 1:27b aan dat die geslagte gelyk is. Die enigste onderskeid lê volgens hom in hulle verskillende rolle ten opsigte van prokreasie. Didimos onderskryf die Aleksandrynse siening dat die vrou wel na die beeld van God geskape is. Wanneer hy geslagtelikheid analogies gebruik, wys hy egter op die verskil wat daar tog bestaan tussen 'n manlike en vroulike siel. Die "manlike" is verhewe terwyl die "vroulike" ondergeskik en minderwaardig is. Dit impliseer dat die manlike siel gesag het as leidinggewende komponent, terwyl die vroulike siel ' $n$ passiewe ontvanger is. In die sintuiglike wêreld is iemand of 'n man of 'n vrou en die feit kan nie verander word nie. Maar in die geestelike wêreld kan 'n vrou manlik word en daarmee die gesag verkry om ander te leer en te lei. Die siel kan volmaaktheid bereik alleenlik deur geestelik manlik te word (Vogt 1991:180).

In vroeë hagiografiese literatuur (lewensbeskrywings van "heiliges") word beklemtoon dat heiligheid iets is wat vroulikheid transendeer. Vir 'n vrou om "manlik" genoem te word, was duidelik 'n vorm van goedkeuring. Heelwat bronne bevestig dat die sosiale kontak tussen die geslagte dikwels verduidelik was in terme van metafore waar geslagtelikheid óf geneutraliseer word óf verander word. Waar die vrou manlik geword het, impliseer dit dat vroue heiliges dieselfde gesag gedra het as die mans. "Man" en "manlik" kan verwys na die volledige menslike natuur asook na 'n staat waar geslagtelikheid getransendeer is. "Vrou" en "vroulikheid", aan die ander kant, verwys altyd na minderwaardigheid. Geslagtelikheid word in hierdie literatuur vergeestelik en herdefinieer: geslagtelikheid is nie gegewe nie, maar kan verander in die innerlike mens. Geslagtelikheid in hierdie konteks hang af van die geestelike vooruitgang van die persoon. Dit bepaal of verlossing behaal sal word of nie (Vogt 1991:182-183, 185).

Wat die patristiese literatuur betref, gaan Justinus (oorlede ca $165 \mathrm{nC}$ ) en Irenaeus (oorlede ca $200 \mathrm{nC}$ ) uit van die vooronderstelling dat Eva met haar sonde haarself vervreem het van die moontlikheid om "beeld van God" te wees. Hulle plaas Maria se gehoorsaamheid aan God teenoor Eva se ongehoorsaamheid. So kompenseer Maria vir Eva. In De culturu feminarum $(1,2,5 ; \operatorname{CCSL} 1,346)$ spreek Tertullianus (oorlede ca 220) vroue direk aan oor die sondeval: "You are the one who opened the door to the Devil, you first plucked the fruit of the forbidden tree and deserted divine law. You are the one who persuaded him whom the Devil was not strong enough to attack. All too 
easily you destroyed the image of God, man" (Engelse vertaling van Tertullianus in Børresen 1991a:190).

Die geïnkarneerde Christus, met die hulp van die gehoorsame Maria, het egter die beeld van God in die mens herstel. Ambrosiaster, 'n ongeïdentifiseerde kommentator op die Pauliniese corpus wat kom uit die laat vierde eeu, beklemtoon dat vroue nie as beeld van God geskape is nie. Dit is uitsluitlik mans se voorreg om beeld van God te wees. Adam dra sy status as "beeld van God" oor aan sy manlike nageslag. Alle vroue erf van Eva 'n God-vervreemde ondergeskiktheid. Hy haal 1 Korintiërs 11:7 aan om vroue se "God-gewilde" ondergeskiktheid te regverdig. Hierdie eksegese van Ambrosiaster is later toegeskryf aan Ambrosius en Augustinus, en het as sodanig gedurende die Middeleeue neerslag gevind in die Rooms-Katolieke geloofsvoorskrifte (canon laws). Daarvolgens is ondergeskikte status vir vroue in die kerk en samelewing vasgelê. Ambrosiaster se kommentaar op 1 Korintiërs 11:7 beklemtoon dat vroue, vanweë hulle ondergeskiktheid, onderhewig is aan die mag (imperium) van die man. Omdat vroue nie beeld van God is nie, moes ook Christelike vroue 'n sluier dra. Die feit dat vroue in gebreke bly om beeld van God wees, was gebruik as regverdiging vir die ondergeskikte posisie wat vroue in die kerk beklee het. Hoewel Ambrosiaster se eksegese verskil het van die Antiogeense, was die gevolgtrekking in hierdie geval dieselfde: mans se dominansie oor die res van die skepping, vroue ingesluit, is God-gegewe. Ook Diodorus van Tarsus (oorlede voor $394 \mathrm{nC}$ ) het 1 Korintiërs 11:7 gebruik om te beklemtoon dat slegs mans beeld van God is omdat hulle mag oor vroue het. Dieselfde gedagte kan gevind word by Chrysostomos (oorlede 407) (kyk Børresen 1991a:192-193).

Teenoor die vorige duidelike stellings oor die verdorwenheid van vroue van die begin af, meen Klemens van Aleksandrië egter dat vroue se verlossing in Christus teruggryp na die skepping. Aangesien godheid en vroulikheid in daardie tyd algemeen beskou is as fundamenteel onversoenbaar, kan vroue nie net van meet af aan na die beeld van God geskape wees nie. Die enigste verlossingsmoontlikheid vir hulle is "in Christus". Christus se verlossingwerk gryp dus terug na die skepping en so kan vroue tog wel ook beeld van God wees. Verlossing beteken baie spesifiek om verlos te wees van hulle vrouwees. "Beeld van God" is dus 'n nie-geslagtelike konsep. Ten spyte hiervan beskryf Klemens morele en intellektuele volmaaktheid steeds as "volmaakte manlikheid". 
Wat uit so 'n siening voortvloei, beskryf Børresen (1991:196) soos volg: "Consequently, Clement's praise of asexual virtue and intellect in man-like disguise enhances theomorphic women by classifying them as honorary men."

Cirilius van Aleksandrië beskou die eienskappe van die beeld van God in die mens as rasionaliteit, vryheid, heerskappy, heiligheid, onverdorwenheid en "seunskap". Die vraag is of vroue hierby ingesluit word. Hy meen dat vroue wesenlik dieselfde natuur het as mans, maar daar is tog belangrike verskille. Sy siening (uit Homilae paschales 28, 3 [PG 77, 948]) kan soos volg opgesom word:

(M)an is superior, woman inferior; man holds the chief place, woman is subject and subordinate; man has greater honor and glory, even before God, whereas woman is of less esteem ... (W)oman falls short of man's "natural ability". She has not the strength to achieve the virtue of which the male is capable. She is of imperfect intelligence. Unlike her male complement she is dull-witted, slow to learn, unprepared to grasp the difficult and the supernatural; for her mind is a soft, weak, delicate thing ... On the other hand, the male sex is ever elect of God, because it is a warrior breed, because it is capable of coming to spiritual vigor, capable of sowing seed, of teaching the rest, of tracing its steps to the mature measure of the fulness of Christ.

(Burghardt 1957:128-129)

Gregorius van Nissa in Kappadosië (331/40 ca) sluit vroue wel in by geskape wees na die beeld van God. Dit word moontlik omdat hy "beeld van God" by die skepping sien as 'n pre-geslagtelike voorreg. Die eerste skepping was naamlik suiwer geestelik. Hierdie volmaakte staat van menswees sal weer herstel word deur die verlossing in Jesus Christus. Tydens die tweede skepping is liggaamlikheid geskape en het sterflikheid en sonde in die spel gekom. Sowel die liggaamlikheid van mans as dié van vroue is vir hom tweederangs (vgl Köstenberger 1997:111). Hy gebruik Galasiërs 3:28 as voorbeeld van die pre-geslagtelike beeld van God wat herstel sal word deur die verlossing. Alle geslagtelikheid sluit die konsep "beeld van God" uit. Wat name vir God betref, is sowel manlike as vroulike name volgens Gregorius totaal onvoldoende. 
"Vader" en "moeder" is nie een geskik om na die werklikheid van God te verwys nie (kyk Børresen 1991a:197).

Teenoor die voorafgaande dualistiese denke oor "manlik" en "vroulik", bevestig Augustinus die eenheid van die skepping. Hy verbind die geslagtelike differensiasie in Genesis 1:27b-28 met die voorafgaande "beeld van God"-teks in Genesis 1:26-27a. Ten opsigte van 1 Korintiërs 11:7 stel hy dat vroue wel geskape is na die beeld van God. (Patristiese eksegese verstaan hierdie teks as 'n bevestiging dat slegs mans geskape is na die beeld van God.) 'The site of the image, the mens or the 'inner man', is part of man's nature, and it was not taken away by original sin. Because the divine image is rooted in the very nature of man, Augustine will reject the opinion that woman is not equally with man an image of God" (Sullivan 1963:49).

Oor Genesis 1:27-28 sê Augustinus dat die menslike natuur, volledig in albei geslagte, geskape is na die beeld van God (kyk De Trinitate XII.7.10). Augustinus handhaaf egter wel die onversoenbaarheid van die begrippe "vroulikheid" en "beeld van God". Hy sien dit so dat vroue wel beeld van God is ten spyte van hulle liggaamlike geslagtelikheid. Vroue kan dit volgens hom wel wees vanweë die verlossing in Jesus Christus wat terugwerkend geld tot by die skepping. Mans, aan die ander kant, is beeld van God vanweë hulle inherente hoür geestelike manlikheid. Om vroue uit te sluit op die vlak van Godheid, is 'n basiese kenmerk van Augustinus se spreke oor God. Vir Augustinus verteenwoordig man en vrou saam die volle mensheid en dus saam die beeld van God. As die man alleen staan, is hy wel beeld van God. As die vrou alleen staan, is sy egter nie beeld van God nie. Wanneer man en vrou saam ' $n$ eenheid vorm, is die manlike komponent van meer waarde en die vroulike komponent minderwaardig. Dit word uitgespel in Augustinus se De Trinitate 7.7.10 (vertaling in Coll 1994:72):

\footnotetext{
Woman together with her husband is in the image of God so that the whole substance may be one image; but when she is referred to separately in her quality of helpmate, which regards women alone, then she is not in the image of God. But as regards man alone, he is the image of God as fully and completely as when woman is joined to him in one.
} 
Augustinus beklemtoon dat prokreasie die enigste rede is waarom vroue geskape is. As dit net gegaan het oor die feit dat die man alleen was en 'n behoefte aan kameraadskap gehad het, sou 'n manlike maat beter gewees het vir ware kameraadskap en gesprek. Wanneer Augustinus die finale herstel van die "volmaakte mensheid" beskryf, sien hy dit egter nie so dat vroue manlik gaan word nie. Vroue sal wel opstaan uit die dood as vrou, maar hulle prokreatiewe funksie sal wegval. Vroue sal dus bevry wees van hulle inherente liggaamlike korrupsie. Vroueliggame sal mans nie meer ná die opstanding kan verlei nie, want die mans sal ook verlos wees van hulle sondige liggaamlikheid. "Vrou" is dus net soveel skepping van God as wat "man" is. Die onderdanigheid van Maria/kerk as Christus se moeder/bruid verseker dat vroue ook gered kan word (kyk Børresen 1991a:202-204).

\section{DIE MIDDELEEUE}

Vroeg-Middeleeuse eksegese van Genesis 1:27 en 1 Korintiërs 11:7 haal dikwels Ambrosiaster aan en kombineer dit met die interpretasies van Ambrosius en Augustinus. Om hierdie uiteenlopende stof saam te bind, fokus die kommentatore op die gedagte van "inklusiewe verlossing". Vroue word wel gesien as beeld van God. 'n Uitsondering hierop is Abelardus (oorlede 1143). Volgens hom is vroue geskape "in God's resemblance, but not in his image" (Børresen 1991b:211-212). Ellen Ross (1990:101) beoordeel die tendens ten opsigte van geslagtelikheid en die konsep "beeld van God" in die Middeleeue soos volg en maak 'n aanbeveling oor hoe hierdie tekste gelees kan word:

\footnotetext{
Despite the symbolic female/male differences wherein woman represents the physical and man the spiritual, for the most part the medieval tradition affirmed that women and men are equally images of God ... (W)e must read these medieval writers with a constant eye to patriarchal distortions, and to inconsistencies in their claims about the human person.
}

Die Fransiskaan Bonaventura (oorlede 1274) aanvaar die vrou as geskape na die beeld van God. Die probleem vir hom is hoe om die voorrang van die man in 1 Korintiěrs 11:7 te verklaar. Hy formuleer dit só dat die man beeld van God is in die eerste 
plek, principaliter, maar nie eksklusief nie. Bonaventura reduseer die vermoë van vroue om beeld van God te kan wees. Vroue kan nie georden word as priester nie, omdat hulle Christus nie kan verteenwoordig nie (representatio). Omdat mans reeds met die skepping voorrang geniet het, kan vroue volgens hom nie priesters word nie. Om as priester te deel in Goddelike mag is 'n eksklusief-manlike prerogatief. Bonaventura legitimeer sy standpunt deur 1 Timoteus 2:12 aan te haal. Hiervolgens kon vroue nie georden word nie, aangesien dit hulle sou laat kwalifiseer om biskop te word. Die tipologiese argument lui dan: aangesien die biskop die bruidegom van sy kerk is, kan 'n vrou nie biskop wees nie. Bonaventura kombineer twee onversoenbare tradisionele motiewe om aan die een kant ' $n$ saak uit te maak dat vroue wel op 'n geslaglose wyse beeld van God is, maar aan die ander kant tog ongeskik is vir priesterskap (kyk Børresen 1991b:214, 216, 218).

Tomas Aquinas (oorlede 1274) bevestig dat vroue geskape is na die beeld van God, maar beklemtoon steeds die primaat van die man. Die ondergeskiktheid van vroue is die gevolg van hulle swakheid ten opsigte van die rede en hulle liggaamlikheid. Vroue as persone is onvolmaak omdat hulle nie die "eintlike mensheid", naamlik die manlike bereik het nie. Vroulikheid is egter nodig om die mensheid te voltooi. Met die opstanding sal vroue ontslae wees van hulle vroulike defekte. Tomas se argument waarom vroue nie priesters kan word nie, is nie omdat hulle Christus nie fisies kan verteenwoordig nie. Vir hom is die rede gewoon bio-sosiaal. Vroue is fisiek minderwaardig en dit het hulle ondergeskiktheid tot gevolg. Daarom kan hulle nie priesters wees nie. Liggaamlike voortreflikheid is nodig om 'n priester te kan wees.

Hierteenoor beskou hy vroue egter wel as geskape na die beeld van God (kyk Børresen 1991b:218, 221, 224). Tomas Aquinas onderskei verder tussen die ondergeskiktheid van vroue en slawe. Slawerny is nie 'n skeppingsordening nie, maar die gevolg van sonde en word alleen verdra omdat dit noodsaaklik is vir die handhawing van die sosiale orde. Die man-vrou hiërargie, aan die ander kant, is wel volgens hom deel van die skeppingsorde (kyk Coll 1994:72). Die Benediktynse abdis, Hildegard van Bingen (oorlede 1179), verwerp ook die moontlikheid dat vroue priesters sou kon word. Sy meen dat vroue vanweë hulle swakheid en passiewe rol in prokreasie, nie die sakramente kan bedien nie (kyk Børresen 1991b:225). 


\section{VOORLOPIGE SAMEVATTING}

In hierdie studie is aangetoon dat die tradisies in die Pentateug, veral wat die skeppingstradisies betref, die gelykwaardigheid van man en vrou as beeld van God impliseer. In die Priesterlike tradisie word die verskil tussen die geslagte as 'n biologiese aangeleentheid gesien. Die Jawistiese tradisie vul die Priesterskrywers aan deur ook te fokus op sosiale aspekte soos kameraadskap. Daar is egter ook aangetoon dat hierdie aangewesenheid op mekaar juis binne die patriargale konteks van die tyd die deur open dat vroue uitgebuit kan word. "Patrilokale residensie" is hiervan 'n voorbeeld. Daar is dus eksegete wat meen dat die skeppingsvertellings nie "neutrale" tekste is nie. Hoewel die asimmetrie in die patriargale gemeenskap waarskynlik nie deur Genesis 1:27 betuig word nie, was vroue se "lot" tog onlosmaaklik gebind aan die voorstelling van God as 'n manlike Skeppergod. Die implikasies van hierdie voorstelling kan duidelik in intertestamentere tekste gesien word. Die studie toon aan dat veral Filo se siening dat die hierargie tussen die geslagte 'n skeppingordening is, het die Christelike tradisie oor die posisie van die vrou teenoor die man sterk beïnvloed. 'n Voorbeeld is Origenes wat meen dat geslagtelike differensiasie (en daarom hiërargiese ordening) eers by die eskatologiese einde opgehef sal word. Aangesien die sondeval van die vrou 'n "soteriologie" noodsaak, word vroue in patristiese tekste (bv Justinus) negatief uitgebeeld en word Maria as die "positiewe" teenpool" van Eva gesien. Van hier af ontwikkel die beeld van vroue as persone met 'n God-vervreemde ondergeskiktheid. Die artikel eindig met Thomas van Aquinas se siening dat slawe se "ondergeskiktheid" van mindere kwaliteit as die van vroue is, omdat slawerny nie 'n skeppingsordening is nie! In die volgende deel van die artikel word ' $n$ historiese oorsig van die periode vanaf die Reformasie gebied.

\section{Literatuurverwysings}

Antonelli, J S 1995. In the image of God: A feminist commentary on the Torah. Northvale, $\mathrm{N} \mathrm{J/London:} \mathrm{Jason} \mathrm{Aronson} \mathrm{Inc.}$

Bach, A 1993. Reading allowed: Feminist biblical criticism approaching the millennium. Currents in Research: Biblical Studies 1, 191-215.

Beers, W 1992. Women and sacrifice: Male narcissism and the psychology or religion. Detroit, MI: Wayne State University Press. 
Bird, P 1991. A sexual differentiation and divine image in the Genesis creation texts, in Børresen, K E (ed), Image of God and gender models in Judaeo-Christian tradition. Oslo: Solum Forlag.

Børresen, K E 1981. Subordination and equivalence: The nature and role of woman in Augustine and Thomas Aquinas, tr by C H Talbot. Washington, D C: University of America Press.

- 1991a. God's image, man's image? Patristic interpretation of Genesis 1:27 and I Cor 11:7, in Børresen, K E (ed), Image of God and gender models in Judaeo-Christian tradition. Oslo: Solum Forlag.

- 1991b. God's image, is woman excluded? Medieval interpretation of Genesis 1:27 and I Cor 11:7, in Børresen, K E (ed), Image of God and gender models in Judaeo-Christian tradition. Oslo: Solum Forlag.

Brown, R E 1979. The birth of the Messiah: A commentary on the infancy narratives in Matthew and Luke. New York: Doubleday.

Burghardt, W J 1957. The image of God in man according to Cyril of Alexandria. Washington, DC: The Catholic University of America Press. (The Catholic University of America Studies in Christian Antiquity 14, ed by Johannes Quasten.)

Coll, R A 1994. Christianity and feminism in conversation. Mystic, CT: Twenty-Third Publications.

Daube, D 1957. Evangelisten und Rabbinen. Zeitschrift für Neue Testamentliche Wissenschafi 48, 119-120.

Dibelius, M 1932. Jungfrauensohn und Krippenkind: Untersuchungen zur Geburtgeschichte Jesu im Lukas-Evangelium. Heidelberg: Carl Winters Universitätsbuchhandlung.

Frymer-Kensky, T 1981. Patriarchal family relationships and near eastern law. Biblical Archaeologist 44, 209-214.

Galambush, J 1992. Jerusalem in the Book of Ezekiel: The city as Yahweh's wife. Atlanta, GA: Scholars Press. (SBLDS 130.)

Gasparro, G S 1991. Image of God and sexual differentiation in the tradition of enkrateia, in Børresen, K E (ed), Image of God and gender models in JudaeoChristian tradition. Oslo: Solum Forlag. 
Gispen, W H 1974. Genesis, I: Genesis 1:11-26. Kampen: J H Kok. (Commentaar op het Oude Testament.)

Gössmann, E 1996. The construction of women's difference, in Schüssler Fiorenza, E (ed), The power of naming: A Concilium reader in feminist liberation theology, 198-207. Maryknoll, NY: SCM.

Howe, L T 1995. The image of God: A theology for pastoral care and counseling. Nashville: Abingdon.

Hultgård, A 1991. God and image of woman in early Jewish religion, in Børresen, K E (ed), Image of God and gender models in Judaeo-Christian tradition. Oslo: Solum Forlag.

Köstenberger, A J 1997. Ascerțaining women's God-ordained roles: An interpretation of I Timothy 2:15. Bulletin for Biblical Research 7, 107-144.

Ljung, I 1989. Silence or suppresion: Attitudes towards women in the Old Testament. Stockholm: Almqvist \& Wiksell. (Acta Universitatis Upsaliensis, Uppsala Women's Studies, Women in Religion 2.)

Malina, B J [1981] 1993. The New Testament world: Insights from cultural anthropology. Revised edition. Louisville, KY: Westminster/John Knox.

- 1996. Understanding New Testament persons, in Rohrbaugh 1996:41-61.

Mattila, S L 1996. Wisdom, sense perception, nature, and Philo's gender gradient. Harvard Theological Review 89(2), 103-129.

Meyers, C L 1988. Discovering Eve: Ancient Israelite women in context. New York: Oxford University Press.

Micks, M H 1982. Our search for identity: Humanity in the image of God. Philadelphia: Fortress.

Moxnes, H 1996. Honor and shame, in Rorhrbaugh 1996:19-40.

Osiek, C \& Balch, D L 1997. Families in the New Testament world: Households and house churches. Louisville, KY: John Knox. (The Family, Religion, and Culture, ed by D S Browning \& I S Evison.)

Rohrbaugh, R (ed) 1996. The social sciences and New Testament interpretation. Peabody. MA: Hendrickson. 
Ross, E M 1990. Human persons as images of the divine: A reconsideration, in Bach, A (ed), The pleasure of her text: Feminist readings of biblical and historical texts, 97-116. Philadelphia: Trinity Press International.

Ruether, R R 1991. Imago Dei, Christian tradition and feminist hermeneutics, in Børresen, K E (ed), Image of God and gender models in Judaeo-Christian tradition. Oslo: Solum Forlag.

Seebass, H 1996. Genesis I: Urgeschichte $(1,1-11,26)$. Neukirchen-Vluyn: Neukirchener Verlag.

Trible, P 1978. God and the rhetoric of sexuality. Philadelphia: Fortress. (Overtures to Biblical Theology.)

Van Wijk-Bos, J W H 1995. Reimaging God: The case for Scriptural diversity. Louisville, Kentucky: John Knox.

Vogt, K 1991. "Becoming male": A Gnostic and early Christian metaphor, in Børresen, $\mathrm{K} \mathrm{E}$ (ed), Image of God and gender models in Judaeo-Christian tradition. Oslo: Solum Forlag.

Wevers, J W 1969. Ezekiel. London: Thomas Nelson. (The Century Bible New Series.) 